ROCZNIKI PEDAGOGICZNE

Tom 11(47), numer specjalny - 2019

DOI: http://dx.doi.org/10.18290/rped.2019.11s-12

MAŁGORZATA IMPEROWICZ-JURCZAK

ROBERT JURCZAK

\title{
NEUROEDUKACJA A NIESPECYFICZNE PROBLEMY W NAUCE DZIECI I DOROSŁYCH
}

Każdy etap życia człowieka wiąże się z koniecznością uczenia się i zdobywania nowych umiejętności oraz adaptacją do warunków, w których zachodzi proces zdobywania wiedzy. Inaczej uczy się niedojrzały mózg dziecka, a inaczej osoby dorosłej, u której zasoby biologiczne mózgu ulegają ciągłym procesom starzenia się. Te skomplikowane procesy odbierania i przetwarzania bodźców widoczne są w zachowaniu i trudnościach w uczeniu się. Osoby dorosłe najczęściej podkreślają problem wypalenia zawodowego i uskarżają się na złą pamięć, ,gonitwę myśli”, życie w ciągłym stresie i zaburzenia snu. Natomiast dzieci z nieprawidłowym funkcjonowaniem obszarów mózgu odpowiadających za uwagę słuchową, koncentrację na zadaniu, naukę, zapamiętywanie są postrzegane przez nauczycieli jako kłopotliwe. Nadruchliwe, rozkojarzone dzieci drażnią dorosłych i rówieśników z powodu nieumiejętności hamowania własnych reakcji (agresja słowna i fizyczna). Ich rodzice zauważają zaburzony rytm snu, rozdrażnienie i konieczność wielokrotnego powtarzania polecenia. Są sfrustrowani uwagami innych dorosłych na temat złego wychowania dziecka. Takich uczniów cechuje zła organizacja - ciągle coś gubią, nie pamiętają zadanych prac lub wykonują je z z niechęcią. Codziennym doświadczeniom towarzyszy wysoki poziom lęku, obniżona samoocena i kłopoty w relacjach z rówieśnikami. Wobec innych dzieci mogą być one zaczepne (tzw. poszukiwacze wrażeń), nadwrażliwe (hipersensitive child) lub podwrażliwe (każdy bodziec dla nich to za mało; np. zbyt wolno kręci się karuzela, jedzenie jest

Dr Malgorzata Imperowicz-Jurczak - Poradnia Terapeutyczna Jaś i Małgosia w Koninie.

Dr Robert Jurczak - Państwowa Wyższa Szkoła Zawodowa w Koninie, Katedra Bezpieczeństwa Wewnętrznego i Informatyki, ul. Przyjaźni 1,62-510 Konin; e-mail: rjurczak@vp.pl; ORCID: 0000-0003-3149-7497 
nie dość chrupiące i jest go ciągle za mało, a nauczyciel zawsze niewyraźnie objaśnia zadania).

Neuroedukacja wspiera dzieci i dorosłych w niespecyficznych problemach w nauce. Już w latach 70 . XX stulecia rozpoczęto prace nad potrzebą stymulacji neuronów w procesach: przyswajania wiedzy, zwiększania potencjału mózgu, zapamiętywania i uwagi. Neurodydaktyka atrakcyjnie (np. stymulujące gry edukacyjne, muzyka, ciekawe ćwiczenia ruchowe integrujące neuronalne przewodzenie między półkulami lewą i prawą mózgu, zwierzęta jako motywator) wspiera harmonijny rozwój człowieka w każdym wieku, osoby zdrowe i z różnymi niepełnosprawnościami (por. Pierzchała, 2006; Pierzchała, 2018).

Liczne metody neurorehabilitacji oraz neuroterapii pozwalają na zidentyfikowanie problemu i skuteczny trening nieprawidłowo funkcjonujących obszarów mózgu, połączony z celowo dobranymi ćwiczeniami ruchowymi. Istotne są tu: prawidłowa lateralizacja (mowa, wzrok i słuch, ręka, noga), integracja bodźców sensomotorycznych oraz ich separacja (odporność na dystraktory). Ze względu na bogactwo metod neuroterapii ograniczymy się do omówienia dwu przypadków (dziecko 8-letnie i dorosły mężczyzna w wieku 56 lat) wspieranych metodami neurofeedbacku i Indywidualnej Stymulacji Słuchu metodą Kjelda Johansena (JIAS).

\section{LATERALIZACJA I METODY JEJ BADANIA}

Wstępnym, istotnym ustaleniem jest określenie lateralizacji (stronności). Służą temu precyzyjnie, np. w metodzie Johansena, dobrane testy, badanie monouralne i binauralne oraz test dychotyczny. Natomiast za pomocą lateralnej prezentacji bodźców można określić szybkość i precyzję wykonania zadania w zależności od tego, do której półkuli bodziec jest adresowany i która, w związku z tym, musi przynajmniej zapoczątkować jego analizę. Najczęściej stosuje się różnorodne bodźce wzrokowe prezentowane na monitorze (np. jak w metodzie neuroflow), prezentowane na bardzo krótki czas w lewym lub prawym polu widzenia, podczas gdy osoba badana wpatruje się w położony centralnie punkt fiksacji. Stosowanie krótkotrwałych ekspozycji (krótszych niż latencja ruchu oka) uniemożliwia badanemu przeniesienie wzroku z punktu fiksacji na inne miejsce w czasie prezentacji bodźca. Powoduje więc, że obraz rzutowany jest na określoną połowę siatkówki, mającą połączenie z określoną półkulą. Bodźce eksponowane na prawo od punktu fiksacji trafiają najpierw do półkuli lewej, bodźce zaś eksponowane na lewo od punktu fiksacji trafiają najpierw do półkuli prawej. 
Półkule mózgowe są ze sobą połączone licznymi włóknami, informacja adresowana do każdej z nich jest przesyłana również do półkuli sąsiedniej. Jak to się więc dzieje, że poprawność oraz szybkość wykonania zadania zależą od tego, do której półkuli bodziec jest adresowany. Niektórzy autorzy sądzą, że pewne zadania są wykonywane przez półkulę, która jest bezpośrednio pobudzana przez bodziec, a dopiero rezultat tych operacji jest przekazywany do drugiej półkuli. Hipoteza ta nazywana jest hipotezą „bezpośredniego dostępu” (direct access). Inni autorzy sądzą z kolei, że analiza określonych informacji czy też wykonanie określonych operacji angażuje tylko jedną, zawsze tę samą półkulę. Dana informacja może być przekazywana do półkuli, która ją opracowuje, albo bezpośrednio, albo pośrednio poprzez półkulę sąsiednią i połączenia międzypółkulowe. Taka pośrednia, dłuższa droga transmisji z reguły wiąże się z pewną stratą informacji oraz z wydłużeniem czasu jej analizy. Hipoteza ta jest określana mianem hipotezy „transmisji międzypółkulowej” (callosal relay). Im więcej nieprawidłowych punktów aktywacji fal mózgowych, tym gorsze funkcjonowanie behawioralne.

Poziom wykonania każdego zadania zależy od względnego pobudzenia każdej z półkul mózgowych. Zadania, które angażują daną półkulę bardziej niż drugą, powodują większą aktywację tej półkuli. To zaś z kolei ułatwia kierowanie uwagi na kontralateralną stronę pola widzenia. W konsekwencji dane zadanie jest lepiej wykonywane, gdy bodziec jest eksponowany do pola położonego przeciwstronnie względem półkuli bardziej pobudzonej.

Chociaż ciągle nie jest jasne, która $\mathrm{z}$ omawianych hipotez jest prawdziwa, każda z nich przewiduje lepsze i/lub szybsze wykonanie zadania, gdy bodźce są eksponowane w polu widzenia przeciwstronnym do półkuli specjalizującej się w tym zadaniu. Założenie to stanowi podstawę badania asymetrii półkulowej za pomocą metody lateralnej prezentacji bodźców.

Metoda lateralnej prezentacji nie ogranicza się jedynie do wzroku. Stosuje się ją również w zadaniach słuchowych oraz dotykowych. Podobnie jest z bodźcami dźwiękowymi podawanymi do prawego ucha ze wzmocnieniem $+5 \mathrm{~dB}$ w metodzie Indywidualnej Stymulacji Słuchu (JIAS) metodą Johansena. W przypadku słuchu informacja z każdego ucha trafia do obu półkul, jednak liczba włókien skrzyżowanych (przekazujących informację z ucha leżącego przeciwstronnie) jest większa. Uważa się, że w warunkach rozdzielnousznego słyszenia (dichotic listening), tj. wówczas, gdy odmienne bodźce prezentuje się jednocześnie do jednego i drugiego ucha, drogi tożstronne (wiodące do półkuli leżącej po tej samej stronie co ucho) są hamowane przez drogi przeciwstronne. W konsekwencji informacja $\mathrm{z}$ lewego ucha trafia przede wszystkim do prawej półkuli i odwrotnie - informacja z prawego ucha do półkuli lewej. 
Metoda rozdzielnousznego słyszenia zdobyła ogromną popularność ze względu na wysoką zbieżność wyników uzyskanych za jej pomocą z wynikami próby Wady. W przypadku zadań dotykowych porównuje się ich wykonanie lewą i prawą ręką i wnioskuje o funkcji odpowiednio prawej i lewej półkuli, opierając się na założeniu, że drogi somatosensoryczne są skrzyżowane (Górska, Grabowska, Zagrodzka, 2012).

\section{ANALIZA PRZYPADKU 1}

\subsection{JAKOŚCIOWE EEG ORAZ JIAS JAKO KRYTERIA OCENY TRUDNOŚCI W UCZENIU SIĘ I APD}

Mama ośmioletniej dziewczynki opisała córkę jako bardzo wrażliwą, łatwo wpadającą w gniew. Dziecko skarżyło się na złe zachowania koleżanek wobec niej, hałas w szkole i przeciążenie nauką (druga klasa szkoły podstawowej). Pod koniec klasy pierwszej pojawiły się pierwsze niepowodzenia i rozczarowanie relacjami rówieśniczymi. Dziewczynka często była zwalniana ze szkoły z powodu bólu brzucha, a w domu - rozdrażniona, płaczliwa, miała problemy z zaśnięciem i wstawaniem.

Do zbadania problemów zastosowano jakościowe EEG (mapowanie mózgu z 19 punktów) oraz badanie uwagi słuchowej metodą IAS Johansena, celem zdiagnozowania APD (czyli zaburzeń przetwarzania słuchowego).

W badaniu ilościowego EEG zauważalne nieprawidłowości w obszarze kory przedczołowej potwierdziły trudności dziewczynki w pamięciowym opanowaniu treści oraz matematyce. Niemożność powtórzenia tego, co mówili nauczyciele i koleżanki w szkole, jak trzeba przygotować się do następnych zajęć, gubienie rzeczy, przedmiotów przez dziewczynkę tłumaczyła nieprawidłowa aktywność obszarów grzbietowo-bocznych kory przedczołowej mózgu. Kłopotów w płynnym wysławianiu się dziecka w momentach zdenerwowania (niepatologiczne jąkanie: replikowanie wyrazów, fraz, rewizje) dopatrzyć się można było w nieprawidłowej aktywności fal w okolicach lewej kory czołowej. Rodzice podkreślali, że denerwują się, gdy dziecko powtarza wyrazy, zacina się (badania lekarskie wykluczyły jąkanie patologiczne oraz niedosłuch). Impulsywne reakcje wynikały z zaburzeń procesów związanych z funkcjonowaniem okolicy przyśrodkowej $(\mathrm{Fz} / \mathrm{Cz})$, która odpowiada za inicjowanie właściwych reakcji i hamowanie niepożądanych.

Skrzyżowana lateralizacja prawa ręka - lewe oko - lewa stronność mowy oraz nieprawidłowości w obrazie ilościowego EEG w obszarze kory sensomotorycznej 
potwierdziły spostrzeżenia matki, że dziewczynka, pomimo doskonałego przygotowania do prac pisemnych, popełnia niespecyficzne pomyłki w zapisach działań liczbowych, słownych, które nie są charakterystyczne dla dysgrafii. Nieprawidłowości w aktywacji mózgu wpływały na behawior dziewczynki, która pomimo swych zdolności, była postrzegana przez nauczycieli jako dziecko mądre, ale rozgadane, nieuważne na lekcji, drażliwe.

Badanie uwagi słuchowej metodą JIAS według szwedzkiego testu dychotycznego KVK non-words wykazało ponadto również słabą odporność dziecka na dystraktory, trudności w skupieniu uwagi, gdy jest szum w klasie i podczas pracy w grupach. Wyraźnie wynik wskazywał na problem z utrzymaniem uwagi słuchowej i pamięcią słuchową krótkotrwałą (APD). Na przykład mama często słyszała uwagi nauczycielki, że córka rzadko potrafi powtórzyć to, co przeczytali na głos na lekcji w klasie, bo jest niegrzeczna i gadatliwa. Niejednorodna dominacja ucha prawego w badaniu audiometrycznym, słabe wyniki testów uwagi słuchowej korelowały z wynikiem badania mapowania mózgu ilościowe EEG.

Co więcej, te niespecyficzne problemy w nauce i impulsywne zachowanie dziecka wpłynęły na obraz dziewczynki w klasie. Była ona postrzegana jako osoba, która nie jest wyróżniana przez panią w klasie, mniej zdolna od pozostałych. Relacje z koleżankami wpłynęły na osamotnienie dziewczynki w grupie rówieśniczej i bardzo niską samoocenę.

Uświadomienie rodzicom złożonych mechanizmów zachodzących w mózgu w procesie uczenia się i przetwarzania informacji, ich wpływu na zachowania córki uspokoiło ich. Nie postrzegali już oni swojego dziecka jako innego, przestali porównywać porażki dziecka z sukcesami rówieśnikami. Zapisali dziewczynkę na basen i zajęcia baletu, na które uczęszczała nieregularnie ze względu na stan zdrowia.

Przez rok dziecko odbywało treningi audioterapii metodą Johansena IAS z kilkutygodniowym etapem ćwiczeń ruchowych integracji międzypółkulowej oraz kynoterapii. Pierwsze efekty były natychmiastowe: od razu zaczęła lepiej spać i popełniała tylko nieznaczne błędy graficzne. Poprawiła się także jej komunikacja z koleżankami. Stała się mniej ruchliwa i bardziej uważna, wyciszona.

Po pięciu miesiącach audioterapii nastąpiła niechęć do tego typu stymulacji oraz zmęczenie muzyką, więc zaproponowano terapię typu neurofeedback w trzech treningach: w części przedczołowej, czołowej, przyśrodkowej i tylnej zakrętu obręczy mózgu. Protokoły treningowe Theta/Beta 1 oraz Theta/SMR miały na celu zmniejszenie impulsywności dziecka, poprawienie organizacji i wydłużenie wolicjonalnego podtrzymania uwagi w sytuacji 
zadaniowej, zapamiętywania poleceń oraz wzmocnienia odporności na przykre doświadczenia.

Po przerwie nastąpiła również kontynuacja treningu uwagi słuchowej, gdyż wyniki testu odbiegały od normy dla danej grupy wiekowej, wskazując na APD (zaburzenia uwagi słuchowej).

Roczne neurotreningi dały pożądany efekt, widoczny zarówno w badaniu EEG, testach APD, jak i w behawiorze. Dziecko dobrze radzi sobie zarówno w nauce, jak i w relacjach rówieśniczych (ma swoją ulubioną koleżankę), nieźle organizuje etapy pracy, zanikła niepłynność mowy. Dziewczynkę nadal wyróżnia emocjonalność, ale ustąpiły niepohamowane reakcje impulsywne (histeryczny płacz w szkole i domu, złość, agresja słowna i fizyczna), łatwiej też znosi porażki i rozumie niepożądane zachowania i uwagi koleżanek. Dużo zapamiętuje $\mathrm{z}$ lekcji i jest aktywna na zajęciach. Zmianę w zachowaniu dziewczynki zauważyli nauczyciele, co poprawiło samoocenę dziecka.

\section{PRZYPADEK 2}

\subsection{NEUROEDUKACJA DOROSŁYCH}

Mężczyzna, 56-letni pracownik umysłowy, uskarżał się na przemęczenie, wypalenie zawodowe, zaburzenia rytmu dobowego, ciągły stres i trudniejsze niż do tej pory zapamiętywanie nowych wiadomości.

Czynniki stresowe powodują nadmierną aktywację osi HPA (podwzgórze-przysadka-nadnercza), co prowadzi do nadmiernego wydzielania kortykoliberyny (badanie krwi może wykazać podwyższoną obecność kortyzolu i wazopresyny). Nadmierne wydzielanie ACTH i kortyzolu zaburza fazy snu oraz wywołuje stany lękowe. Przyczyny nadaktywności osi HPA upatruje się w okołoporodowych mikrouszkodzeniach mózgu (konflikt serologiczny, wysoki poziom bilirubiny po urodzeniu) lub przeżyciach z dzieciństwa (trauma).

Badanie ilościowe EEG nie wykazało zmian morfologicznych, natomiast wskazało na nieprawidłowości w nadaktywacji fal w obszarach przedczołowych i grzbietowo-bocznych kory czołowej. Taka nieprawidłowość w funkcjonowaniu kory przedczołowej powoduje nieodporność na dystraktory, impulsywność, kłopoty z pamięcią i tendencję do zapominania. Prawidłowe skomunikowanie płatów przedczołowych z płatami potylicznymi wpływa na stan relaksu. Gdy stan ten jest nieprawidłowy, organizm nie odpoczywa efektywnie.

Konieczna w tej sytuacji stała się zmiana nawyków mężczyzny związanych z pracą umysłową. Ruch jest niezbędnym elementem efektywnej pracy 
intelektualnej, dlatego praca fizyczna w ogrodzie oraz jazda na rowerze (ulubiony sport) zostały wpisane jako stały element neurotreningu.

Neurotreningi w obszarach kory przedczołowej Beta 1 /Theta (Fp1) oraz SMR/Theta (C4; P4). Audiotreningi nazywane są potocznie siłownią dla mózgu. Dlatego zastosowany został rownież indywidualny trening IAS metodą Johansena $\mathrm{z}$ wykorzystaniem dudnienia różnicowego Hemi Waves $20 \mathrm{~Hz}-10 \mathrm{~Hz}-15 \mathrm{~Hz}$. Wysokie tony wzmacniają fale Beta 1, odpowiadające za myślenie i działanie, codzienną świadomość. Niższe, podawane po trzech minutach, wprowadzają mózg w stan relaksu, który wywołują fale Alfa (odprężenie, poczucie spokoju, kreatywność, relaksacja, dobry nastrój). Potem znowu powraca się do fal Beta 1. Takie różnicowanie tonowe wywołuje głęboki relaks i ćwiczy uwagę.

Efektem neurotreningów była większa odporność na stres związany z pracą, widoczna w EEG, oraz umiejętność relaksacji, nieco polepszyła się pamięć. Nie nastąpiła poprawa, jeśli chodzi o osiągnięcie tzw. intelektualnego momentu szczytowego - pick up (widoczny brak zmian w EEG). Neurotrening w wieku dojrzałym jest bardzo potrzebny ze względu na mniejszą plastyczność mózgu niż u ludzi młodszych. Efektywna praca mózgu związana jest z dobrym funkcjonowaniem hipokampu, który wraz z wiekiem ulega zmianom i praca umysłowa staje się większym wysiłkiem.

\section{WNIOSKI}

Neurofeedback w procesie uczenia się wykorzystuje sprzężenie zwrotne i zapis EEG. Audioteapia JIAS jest „siłownią” dla mózgu i narządów słuchu; treningiem kory mózgu w celu ćwiczenia uwagi słuchowej oraz lepszego rozumienia mowy w hałasie i sytuacjach stresogennych. Są to metody interesujące, gdyż nie ingerują w żaden sposób w system wartości człowieka. Terapeuta nie odwołuje się do doświadczeń i światopoglądu osoby trenującej ani nie sugeruje swoich lub nabytych przekonań. Przeprowadza on za pomocą medycznego urządzenia odpowiednie protokoły treningowe (głowica EEG $\mathrm{z}$ oprogramowaniem neurofeedbacku) lub na podstawie audiogramu (audiometr MAICO) i testów rozumienia mowy dobiera indywidualny program (muzyka Benta Holbecha do słuchania przez 8-10 miesięcy), który stymuluje korę mózgu i wspiera słyszenie. Terapeuta obserwuje i analizuje za pomocą pomiarów EEG, QEEG lub audiogramu i testów APD (zaburzenia przetwarzania słuchowego) zmiany w krzywej uczenia się i postępy w rozumieniu mowy. Najlepsze efekty uzyskuje się u dzieci ze względu na ogromną plastyczność mózgu w tym 
wieku (analiza Przypadku 1). W wieku dojrzałym (analiza Przypadku 2) różne formy neuroedukacji mogą być pomocną formą rehabilitacji nieprawidłowo funkcjonujących obszarów mózgu.

Neuroedukacja, wykorzystująca wiedzę o uczeniu się na poziomie neuronalnym, wspiera naturalny potencjał mózgu do uczenia się i rozumienia mowy. Za pomocą indywidualnych ćwiczeń wykorzystujących zapis EEG możemy zharmonizować amplitudy fal zakłóconych stresem lub morfologią mózgu, zintegrować pracę półkul mózgowych, wzmacniać lateralizację. Muzyka (audioterapia) natomiast rehabilituje na poziomie neuronalnym; zmysł słuchu ostatni zamiera w momencie śmierci mózgu. Niezbędnym elementem każdego treningu jest ruch angażujący i integrujący pracę obu półkul.

Skuteczną metodą jest kynoterapia. Pies nie ocenia, ale w sposób nieświadomy dla człowieka oddziałuje stymulująco na wiele zmysłów. Odpowiednio dobrany program ćwiczeń ruchowych i intelektualnych, podczas których wyszkolony pies jest motywatorem do wykonywania zadań terapeutycznych, stanowi skuteczną rehabilitację w każdym wieku.

Efekty neuroedukacji widoczne są na wielu płaszczyznach: w zachowaniu i samoocenie człowieka, postępach w nauce, kontaktach międzyludzkich.

\section{BIBLIOGRAFIA}

Górska, T., Grabowska, A., Zagrodzka, J. (2012). Mózg i zachowanie. Warszawa: Wydawnictwo Naukowe PWN.

Marcus, L. V., Fields, M. C., Yoo, J. (2017). Podstawy EEG z miniatlasem. Red. wyd. pol. A. Sobieszek, I. Domitrz. Wrocław: Edra Urban \& Partner.

Nowak, S., Nowak, P., Nowak, E., Nowak, W. (2004). EEG jako kryterium zdrowia człowieka. Kielce: Studia Medyczne Akademii Świętokrzyskiej.

PierzchaŁa, K. (2006). Poczucie powinności i odpowiedzialności u młodzieży katolickiej. Toruń: Wydawnictwo Adam Marszałek.

Pierzchata, K. (2018). Możliwości kształcenia ustawicznego służby więziennej oraz osadzonych W: E. Stokowska-Zagdan, J. Flanz (red.), Ksztatcenie ustawiczne. Wymiar interdyscyplinarny (s. 90-98). Skierniewice: Wydawnictwo PWSZ. 


\section{NEUROEDUKACJA A NIESPECYFICZNE PROBLEMY W NAUCE DZIECI I DOROSŁYCH}

\section{Streszczenie}

Neuroedukacja wykorzystuje techniki treningu na poziomie neuronalnym w celu skutecznej stymulacji mózgu w procesie uczenia się zarówno dzieci, jak i dorosłych, osób zdrowych i z niepełnosprawnościami. W artykule zaprezentowano własne wyniki i wnioski dwu cykli treningowych (8-letnie dziecko i 56-letni dorosły) z wykorzystaniem metod: neurofeedbacku, audioterapii, kynoterapii oraz ćwiczeń integracji międzypółkulowej. Metody te okazały się atrakcyjne dla trenujących w każdym wieku, nie wymagały od terapeuty odwoływania się do doświadczeń człowieka, zmiany jego przekonań. Efekty neurotreningu miały na celu wspieranie pracy mózgu, poprawę uwagi słuchowej, wyników uczenia się, pamięci oraz radzenie sobie w sytuacjach stresogennych.

Słowa kluczowe: neuroedukcja; neurotrening; niespecyficzne problemy w nauce.

\section{NEUROEDUCATION AND NONSPECIFIC PROBLEMS \\ IN LEARNING CHILDREN AND ADULTS}

\section{Summary}

Neuroeducation uses training techniques at the neural level to effectively stimulate the brain in the learning process of both children and adults, healthy people and people with disabilities. The article presents author's results and conclusions of the two training cycles (for an 8 -year-old child and a 56-year-old adult) using the methods of: neurofeedback, audiotherapy, kynotherapy and interhemispheric integration exercises. These methods turned out to be attractive for people of all ages, they did not require a therapist to refer to human experiences, change their beliefs. The effects of neurotrening were aimed at supporting the brain work, improving auditory attention, learning outcomes, memory and coping with stressful situations.

Key words: neuroeduction; neurotraining; non-specific problems in learnig. 